This is a self-archived version of an original article. This version may differ from the original in pagination and typographic details.

Author(s): Roiha, Anssi; Mäntylä, Katja

Title: 'It has given me this kind of courage...': the significance of CLIL in forming a positive target language self-concept

Year: 2022

Version: Accepted version (Final draft)

Copyright: @ 2019 Informa UK Limited, trading as Taylor \& Francis Group

Rights: In Copyright

Rights url: http://rightsstatements.org/page//nC/1.0/?language=en

Please cite the original version:

Roiha, A., \& Mäntylä, K. (2022). 'It has given me this kind of courage...': the significance of CLIL in forming a positive target language self-concept. International Journal of Bilingual Education and Bilingualism, 25(1), 100-116. https://doi.org/10.1080/13670050.2019.1636761 


\title{
'It has given me this kind of courage..': The significance of CLIL in forming a positive target language self-concept
}

\begin{abstract}
This article sets out to broaden the understanding of foreign language self-concept in CLIL context. The few existing studies on self-concept in CLIL have been quantitative and provided somewhat discrepant results, highlighting the need for approaching the topic qualitatively. The data of the present study are in-depth interviews with 24 former Finnish CLIL pupils who retrospectively reflected on their CLIL experiences. The participants had received English-medium CLIL for nine years during their comprehensive school in the 1990s. The data were analyzed qualitatively using thematic analysis. The participants generally felt that CLIL had had a significant role in contributing to their very positive English language self-concept. Most reported being highly confident language users who had not experienced any language anxiety in English. However, some participants' selfconcept had oscillated throughout the years. The participants put a lot of emphasis on social comparisons, external feedback and the early start of CLIL in forming their positive English self-concept. The participants' self-concepts in other foreign languages seemed to be more negative. The results indicate that early and fairly moderate CLIL has potential in creating a positive target language self-concept, which encourages to adopt CLIL methodology also to mainstream language education.
\end{abstract}

Keywords: English-medium CLIL, self-concept, foreign language, language users, interview study, Finland

\section{Introduction}

The role of self-beliefs in learning has been broadly acknowledged which explains the increasing attention to psychology of language learning also in recent research. Theories of self and L2 learning have most recently been looked at through a motivational lens: what are the ideal and ought-to selves the learner aspires to become (Dörnyei 2005, 2009; Dörnyei and AlHoorie 2017). Currently, there is a myriad of terms to describe learners' self-beliefs. This study relies on the term self-concept, which has been much applied in psychology and sociology, but sparsely studied in language learning and teaching. Particularly in Content and Language Integrated Learning (hereafter CLIL) context, the adoption of the term has remained scarce as the majority of CLIL studies have focused on learning outcomes (e.g. Dalton-Puffer 2011; Pérez-Cañado 2012). Moreover, the few existing studies on self-concept in CLIL have been quantitative (e.g. Pihko 2007; Rumlich 2016; Seikkula-Leino 2007), highlighting the need for approaching the topic qualitatively.

In this article, CLIL is defined as an educational approach where content is taught partly through a foreign or an additional language. Thus, CLIL entails a dual-, however not necessarily an equal, focus on both language and content learning. (e.g. Coyle, Hood, and Marsh 2010.) The approach has spread widely in Europe in the past few decades although its 
implementation varies across and even within countries. In Finland, CLIL started in 1991 and has gained a stable place in the Finnish education system although its popularity has fluctuated throughout the years (e.g. Lehti, Järvinen, and Suomela-Salmi 2006; Nikula and Marsh 1996; Peltoniemi et al. 2018).

CLIL has been promoted as developing target language learning without detrimental effects on content learning (e.g. Dalton-Puffer 2011; Graham et al. 2018). Less attention has been drawn to pupils' self-perceptions as language learners and users. Thus, this article aims to strengthen that body of research in CLIL context by examining in-depth how former pupils perceive the influence of early CLIL education on their target language self-concept. CLIL as a learning context is unique as it offers language learners more versatile venues to develop their foreign language self-concept than mainstream language education. In CLIL, language is very much seen as functional and a vehicle of action rather than just as target of learning (e.g. Pižorn 2017). Since methods resembling CLIL are gaining more and more popularity in Europe due to trends to promote early language learning, investigating the effects of CLIL on self-concept is significant. Through former CLIL pupils' life-stories and narrations, we explore their reflections on the formation of their foreign language self-concept in an English-medium CLIL context. In this article, we concentrate on two aspects reflected on in the interviews:

1. How is the participants' $(n=24)$ English language self-concept manifested in the interviews?

2. What factors do the participants identify as having influenced their English language selfconcept?

\section{Theoretical framework}

\subsection{Defining self-concept}

The term self-concept stems from psychology where it has been extensively studied (e.g. Burns 1982; Marsh 1990; Marsh, Byrne, and Shavelson 1988; Marsh and Shavelson 1985; Shavelson, Hubner, and Stanton 1976). Self-concept is sometimes confused, and interchangeably used, with self-esteem or self-efficacy (e.g. Bong and Skaalvik 2003; Mercer 2011b). Self-esteem can be viewed as the broadest of the three constructs as it represents one's overall value of oneself (e.g. Harter 2006) whereas self-efficacy refers to one's perceived capability to pursue and reach one's goals in relatively context-specific tasks (Bandura 1986). Self-concept, in turn, 
can be seen as more domain-specific than the generic self-esteem but not as tied to specific tasks and contexts as self-efficacy. Furthermore, self-efficacy is regarded as more cognitive whereas self-concept, albeit being primarily cognitive, can be seen containing also an affective component (e.g. Bong and Skaalvik 2003; Pihko 2007; Tracey et al. 2014). However, as Mercer (2011a) points out, it can be problematic and somewhat unnecessary to rigorously separate the different self-constructs.

Self-concept has been further conceptualized in various ways. For instance, Shavelson, Hubner, and Stanton $(1976,411)$ define self-concept as individual's perceptions of him/herself which are formed through experiences with the environment and influenced particularly by reinforcements and evaluations by significant others. Marsh, Byrne, and Shavelson (1988) view self-concept as a multidimensional and hierarchical construct. At the apex of their selfconcept model is the global self-concept which is divided into academic self-concept and nonacademic self-concept. These two domains are further divided into more specific self-concepts, for instance math academic self-concept and verbal academic self-concept which comprises a holistic foreign languages self-concept.

Self-concept is considered to be an important construct regarding schooling. That is, it has been found to both influence students' motivation to choose certain courses or subjects (e.g. Pesu 2017) as well as predict and determine academic achievement (e.g. Marsh and Craven 2006; Marsh and Köller 2003). For instance, Marsh et al.’s (2005; 2006) studies have indicated that there is a correlation between the different academic components of self-concept and the academic outcomes, and that the relationship between academic self-concept and academic achievement is reciprocal.

\subsection{Self-concept in language learning}

In research on language learning and teaching, too, self-concept has gained attention in recent years (e.g. Csizér and Magid 2014; Mercer 2014), similarly to beliefs and identity (e.g Dörnyei and Ushioda 2009). The theory of motivational self-system, which is fairly influential in the psychology of language learning, introduces the idea of learners' possible selves, including ideal and ought-to self (Dörnyei 2005; Markus and Nurius 1986). The theory of possible selves stems from the idea that individuals are shaped by their experiences which are reflected on their wishes, hopes and fears about their future developments. Thus, self-concept is connected to possible selves. If, for instance, one perceives his/her abilities in learning and using English as good, one's ambitions in learning English are likely to be higher than a learner's who 
perceives him/herself as a poor English speaker. Learners' concepts and identity as users of a given language have indeed been found to be significant in the learning results (Breen 2001; Norton 2013; Pavlenko and Norton 2007; Rubio 2014).

Basing on Marsh, Byrne, and Shavelson's (1988) conceptualization, Mercer (2011b) defines self-concept belonging under the umbrella term of self-beliefs. According to her, selfconcept is 'a dynamic, multidimensional psychological construct, which both influences and is affected by a person's social contexts and interactions and that can vary across individuals and settings but that has a certain degree of internal stability.' (Mercer 2011b, 13-14). In line with Marsh, Byrne, Shavelson (1988), Mercer (2011b) proposes that self-concept functions in different domains. Thus, learner's foreign language learning self-concept represents individual's self-beliefs about oneself as a foreign language learner (Mercer 2011b).

Similarly, relying on the notion of self-concept as a hierarchical structure, and based on empirical findings, Lau et al. (1999) have formed an even more specific English self-concept construct. They propose that, despite some variation between different language skills (i.e. reading, writing, listening and speaking), pupils' overall English skills can be represented by a global English self-concept. Their model has however been challenged as mirroring too much the statistical research design and overlooking more nuanced ways of defining one's selfconcept in more specific domains (e.g. Mercer 2011b).

Additionally, Pihko (2007) has conceptualized the foreign language self-concept (see also Laine and Pihko 1991). She divides it into three components called 1) real/actual self, 2) ideal self and 3) self-esteem/self-worth. According to her, the real/actual self refers to the learner's subjective perceptions and beliefs of oneself as a language learner. The ideal self, in turn, reflects language learner's hopes, wishes and self-demands. Pihko (2007) suggests that self-esteem/self-worth is the most important component of the foreign language self-concept as it represents learners' beliefs in their abilities to learn a foreign language and, thus, has a direct bearing on their learning outcomes.

\subsection{Factors influencing self-concept}

Several factors are considered influencing self-concept. For instance, Marsh's (1986) I/E (internal/external) frame of reference model suggests that self-concept is formed in relation to internal and external comparisons. The internal frame of reference relates to a person's juxtaposition of his/her different self-concepts which may have either a positive or negative effect on other self-concepts. For instance, if a pupil perceives him/herself to be better at 
English than at mathematics, the internal comparison is likely to enhance the pupil's English self-concept and act conversely regarding the math self-concept. The external comparisons, in essence, relate to people comparing their own and their perceived others' self-concepts.

Mercer (2011b), who has investigated self-concept more specifically in a foreign language context, also adheres to the internal/external dichotomy. According to her, internal factors influencing one's foreign language self-concept include internal comparisons across subjects, languages and skills, beliefs about specific languages and language learning in general and affective reactions to the language. External factors, in turn, comprise social comparisons, feedback from close ones, experiences of success/failure and previous language learning/using situations in various contexts. However, Mercer (2011b) acknowledges that the separation of different factors influencing one's self-concept is somewhat arbitrary as they are often interrelated. Pihko (2007) places emphasis on the external factors as she claims that individual's foreign language self-concept is gradually formed in one's learning and communicative situations. That is, positive language experiences facilitate the forming of a high foreign language self-concept whereas negative situations act conversely.

In this article, we use the term English self-concept which we regard as a subcomponent of the global self-concept (e.g. Marsh, Byrne, and Shavelson 1988), and define it broadly as people's beliefs of themselves as language learners and users (e.g. Mercer 2011b). We consider self-concept as having both cognitive and affective components (e.g. Pihko 2007; Tracey et al. 2014). We believe that self-concept is affected by one's experiences, and in turn affects one's choices and in most cases achievement. Our views are further substantiated by the data of the present study.

\subsection{Self-concept in CLIL: Previous studies}

Studies on self-concept in CLIL context have been relatively scarce. Recently, a few studies have investigated learners' self-beliefs in English-medium instruction at the university level (e.g. Doiz and Lasagabaster 2018; Konttinen 2018). In one of the few CLIL studies about selfconcept at basic education level, Seikkula-Leino (2007) examined Finnish $5^{\text {th }}$ and $6^{\text {th }}$ grade CLIL pupils' $(n=116)$ and their non-CLIL peers' $(n=101)$ English language self-concept via a quantitative survey. Although CLIL pupils were somewhat more motivated to learn and use English, their English self-concept was significantly weaker than that of their non-CLIL peers. CLIL pupils perceived themselves as weaker language learners in general and in specific language domains, such as understanding, reading, writing or speaking. Seikkula-Leino (2007) 
speculates that one possible reason for the CLIL pupils' weak self-concept may be the demanding language they are constantly exposed to which can make them feel incompetent and weak learners, thus having a direct bearing on their self-concept. Additionally, the results may mirror the drawbacks of quantitative research as pupils in different groups may have perceived the statements differently.

In another study in Finland, Pihko (2007) investigated quantitatively the differences of lower secondary school CLIL ( $\mathrm{n}=209)$ and non-CLIL pupils' $(\mathrm{n}=181)$ English language selfconcept. Contrarily to Seikkula-Leino's (2007) study, the CLIL pupils' foreign language selfconcept was very high and more positive than of their non-CLIL peers'. Pihko (2007), in turn, deduces that CLIL classes are potential environments for developing pupils' positive foreign language self-concept as pupils are constantly using the language in a meaningful way. As the study did not take the pupils' a priori differences into account, Pihko (2007) contemplates that at least in some cases the CLIL pupils' self-concept could have been initially higher. The study nevertheless showed that CLIL education at least maintains a positive language self-concept.

In a fairly recent study in German CLIL context, Rumlich (2016) examined the English as a foreign language self-concept (hereafter EFL SC) in a study comprising 321 CLIL pupils, 221 non-CLIL pupils (i.e. pupils who attended the same school as the CLIL pupils but did not receive CLIL) and 134 regular pupils (i.e. pupils who studied in a school without a CLIL program). Rumlich (2016) took a priori differences into account and scrutinized the change in pupils' EFL SC for a period of two years. The results revealed that CLIL pupils' EFL SC was higher already at the outset of the research. However, the CLIL pupils' EFL SC slightly increased during the two-year period whereas for regular pupils it remained the same, and slightly decreased for non-CLIL pupils. Rumlich (2016) states that the results regarding the effect of CLIL on pupils' self-concept should be interpreted with caution as the CLIL pupils' initially higher EFL SC seem to explain most of the increase.

In conclusion, the few previous studies on self-concept in CLIL context have mostly been quantitative and provided somewhat discrepant results. Due to the research setting of the present study, we do not attempt to clarify the inconsistency of the aforementioned studies. Rather, we aim to elucidate the nature and development of self-concept in CLIL by examining the issue qualitatively using in-depth interviews. Furthermore, the present study takes on a fairly novel perspective, that is, the focus is on former pupils' perceptions of the long-term effect of CLIL on their English language self-concept.

\section{Research process}




\subsection{Context of the study}

The context of the study is Finland where CLIL has officially been implemented since 1991. Throughout the years, CLIL has established its place in the Finnish education system, although its popularity has decreased substantially since the 1990s (e.g. Lehti, Järvinen, and SuomelaSalmi 2006; Nikula and Marsh 1996). However, according to a very recent survey (Peltoniemi et al. 2018), the number of municipalities offering CLIL education in early childhood education and basic education has again increased in recent years.

The English-medium CLIL program of the target school started in 1991 and the participants of the present study started their schooling in 1992. At that time, only one class per grade level received CLIL. The CLIL program was open to everyone, thus no pre-tests were conducted. However, a requirement was that the pupils did not have noticeable learning difficulties in pre-school. In addition, priority was given to the pupils who had some previous experience in English, which applied to five pupils in the target class. CLIL was implemented on a daily basis. On average, at primary level, the amount of English-medium lessons was approximately 25 percent of all teaching. CLIL did not replace formal English teaching but was carried out alongside it. However, the formal English teaching, which then began in grade 3, was more intensive than typically. CLIL was also implemented in the lower secondary school (grades 7-9, pupils' age 13-15) although its amount diminished and it was more sporadic due to timetable constraints and subject teachers' insufficient competence to give English-medium instruction. The overall aim of the CLIL program was to make the pupils confident language users, thus hinting at a positive self-concept.

\subsection{Methodology}

\subsubsection{Data collection and analysis}

The data for this study are in-depth interviews which were conducted by author 1 between August 2016 and January 2017. Most interviews took place at the interviewer's or the interviewee's home, whereas a few interviews were conducted in a public venue or via Skype

\footnotetext{
${ }^{1}$ The background information comes from an interview with a former teacher of the school and two old program brochures. In addition, author 1 was a pupil in the target CLIL class throughout the entire comprehensive school.
} 
(see Table 1). The interviews lasted from 30 minutes to 79 minutes, the average being 48 minutes. The semi-structured interviews were based on broad themes which were given to the interviewees in advance in order for them to recollect aspects and experiences of their CLIL education (see Roiha and Sommier 2018). Despite the general outline, each interview was slightly different as the participants were given the opportunity to focus on the topics relevant to them and their individual life trajectories. The interview themes stemmed from previous research and literature on CLIL as well as from a pilot study carried out by author 1 (Roiha 2017).

Author 1 had a prior relationship with the participants as he had been a pupil himself in the CLIL class throughout the entire 9-year comprehensive school which added a distinctive feature to the data collection. Garton and Copland (2010) refer to this type of interview setting as acquaintance interviews. According to them, these do not necessarily produce more valid results than other interview types, however the shared experience may enable access to resources not always obtainable in more traditional interview settings.

The interviews were transcribed verbatim by author 1 . The data were analyzed qualitative using theory-oriented thematic analysis (Braun and Clarke 2006). We approached the data with a relatively general conceptualization of foreign language self-concept (cf. Pihko 2007) as we wanted the analysis to be as inductive as possible. Nevertheless, our analysis was informed by the broad conceptualization of self-concept as a multidimensional, dynamic and situational construct. First, the whole data were coded according to emerging themes and the transcribed excerpts relating to self-concept were chosen as the data for this study. This consisted of 50820 words which was equivalent to approximately one-third of the overall data, thus making self-concept a highly prominent theme of the interviews. Next, the different codes were sorted into potential themes and the relevant data excerpts were arranged under the different themes. The analysis resulted in the main overarching themes and their sub-themes (see Appendix 1 as an example). To ensure triangulation (Tuomi and Sarajärvi 2009), the analysis following the initial coding was done by both authors separately.

\subsubsection{Participants}

The participants of the study are 24 adults who took part in the target CLIL class at some stage between years 1992 and 2001 (i.e. primary and lower secondary school). Overall, 29 pupils (including the researcher) were part of the class at some stage of the CLIL program. The participants were informed of the purpose of the study and how the data would be used. 
Furthermore, it was made explicit that they could withdraw from the study at any stage. Additionally, the participants received pseudonyms to conceal their identities (see Table 1 for more details). A brief synopsis of each participant's education and English use can be found in Appendix 2.

Table 1. The participants and the interview details (Adapted from Roiha 2019).

\begin{tabular}{|c|c|c|c|c|}
\hline Pseudonym & CLIL experience & In total & Interview venue & $\begin{array}{l}\text { Interview } \\
\text { duration }\end{array}$ \\
\hline Anna $(F)^{2}$ & pre-school $-9^{\text {th }}$ grade & $=10$ years & researcher's home & $58: 04$ \\
\hline Annika (F) & $1^{\text {st }}-6^{\text {th }}$ grade & $=6$ years & researcher's home & $41: 37$ \\
\hline Arttu (M) & $7^{\text {th }}-9^{\text {th }}$ grade & $=3$ years & hotel lobby & $39: 18$ \\
\hline Eemeli (M) & pre-school $-9^{\text {th }}$ grade & $=10$ years & researcher's home & $45: 44$ \\
\hline Emmi $(\mathrm{F})$ & pre-school $-9^{\text {th }}$ grade & $=10$ years & university library & $40: 22$ \\
\hline Hanna $(\mathrm{F})$ & pre-school $-6^{\text {th }}$ grade & $=7$ years & researcher's home & $30: 17$ \\
\hline Jere $(\mathrm{M})$ & pre-school $-9^{\text {th }}$ grade & $=10$ years & via Skype & $38: 35$ \\
\hline Jonne (M) & $1^{\text {st }}-9^{\text {th }}$ grade & $=9$ years & participant's home & $45: 55$ \\
\hline Juho (M) & $1^{\text {st }}-9^{\text {th }}$ grade & $=9$ years & participant's home & 69:03 \\
\hline Jukka (M) & pre-school $-9^{\text {th }}$ grade & $=10$ years & researcher's home & $34: 54$ \\
\hline Kaapo (M) & $1^{\text {st }}-6^{\text {th }}$ grade & $=6$ years & via Skype & $36: 10$ \\
\hline Kalle (M) & pre-school $-9^{\text {th }}$ grade & $=10$ years & participant's home & $37: 15$ \\
\hline Kimmo (M) & $1^{\text {st }}-9^{\text {th }}$ grade & $=9$ years & participant's home & $63: 18$ \\
\hline Lotta $(\mathrm{F})$ & pre-school $-4^{\text {th }}$ grade & $=5$ years & researcher's home & $34: 07$ \\
\hline Maria $(F)$ & $1^{\text {st }}-6^{\text {th }}$ grade & $=6$ years & hotel lobby & $61: 08$ \\
\hline Marko (M) & $1^{\text {st }}-4^{\text {th }}$ and $6^{\text {th }}-9^{\text {th }}$ grade & $=8$ years & researcher's home & $78: 31$ \\
\hline Niko (M) & pre-school $-9^{\text {th }}$ grade & $=10$ years & via Skype & $39: 30$ \\
\hline Olli (M) & $1^{\text {st }}-9^{\text {th }}$ grade & $=9$ years & researcher's home & $38: 24$ \\
\hline Pasi (M) & pre-school $-9^{\text {th }}$ grade & $=10$ years & researcher's home & $39: 18$ \\
\hline Riikka (F) & $7^{\text {th }}-9^{\text {th }}$ grade & $=3$ years & researcher's home & $45: 24$ \\
\hline Roni (M) & $1^{\text {st }}-9^{\text {th }}$ grade & $=9$ years & participant's home & $41: 22$ \\
\hline Samu (M) & $3^{\text {rd }}-9^{\text {th }}$ grade & $=7$ years & participant's home & $62: 14$ \\
\hline Sanna (F) & $2^{\text {nd }}-7^{\text {th }}$ grade & $=6$ years & via Skype & $79: 56$ \\
\hline Tuukka (M) & pre-school $-9^{\text {th }}$ grade & $=10$ years & researcher's home & $63: 02$ \\
\hline
\end{tabular}

\section{Results}

The Results section presents the main findings in relation to the research questions: 1) manifestation of English language self-concept and 2) factors influencing English language self-concept. Both questions are further divided into sub-themes. The section contains quotes from the participants which have been translated into English by the authors. The original quotes in Finnish are found in Appendix 3.

\subsection{The manifestation of English language self-concept}

\footnotetext{
${ }^{2}$ The letter in the brackets signifies the participants' sex (i.e. $F=$ female, $M=$ male).
} 


\subsubsection{Positive and robust self-concept}

In general, the data suggest that $16^{3}$ participants had a robust English language self-concept. This interpretation was made based on the participants' life courses and how they described themselves as English language users in the interviews. For six participants, in turn, their English self-concept was inferred to have oscillated more throughout the years whereas for two participants, it seemed to be relatively negative. English was still actively present in many of the participants' lives for instance through work or in their spare time (see Appendix 2). They declared being strong and confident language users who trusted their own language skills. Furthermore, 16 participants emphasized that they had experienced none or hardly any language anxiety when using English. Additionally, four of them even considered their English skills being on the same level as their Finnish skills. For instance, Anna referred to herself as 'bilingual'. For four participants, in turn, English seemed to have the status of a second language as they placed it somewhere in between Finnish and other foreign languages. Even traces of superiority as a language user could be identified in 11 participants' interviews which further demonstrates their strong English self-concept:

(1) Finns do speak [English] quite well.. but it is still a bit sometimes.. that they make mistakes that I wouldn't maybe make. (Eemeli)

The data indicate that 15 participants perceived a clear relation between their CLIL education and English language self-concept. For instance, Pasi and Annika mentioned words such as 'courage' or 'self-confidence' when describing the significance of CLIL in relation to their English self-concept:

(2) It $[=\mathrm{CLIL}]$ has given me this kind of courage.. self-confidence to use English. (Pasi)

(3) I trust my language skills.. in a way that you have the courage to start speaking and you have.. like that vocabulary and so.. I would give a lot of credit to it [= CLIL] about this. (Annika)

Interestingly, Annika had not performed so well in English at school and had not used English language consistently after basic education, yet she portrayed a relatively strong English

\footnotetext{
${ }^{3}$ For the sake of transparency, we have quantified the data whenever feasible. However, as the interviews were relatively open in nature, not all themes were covered with all participants. Therefore, the quantifications should only be considered as suggestive indicators.
} 
language self-concept. For instance, Pesu (2017) has pointed out that besides academic success, self-concept development is often impacted by age as well as cultural and individual differences, which may also partly explain Annika's situation. Regardless, this finding provides valuable insights for practitioners not to automatically assume a straightforward relation between pupils' academic outcomes and their self-concept.

No participant regarded CLIL as useless or insignificant to their English self-concept. On the contrary, everyone acknowledged the effect of CLIL on them as language users to a varying degree. Five participants, for instance, explicitly speculated that other factors might have influenced and contributed to their positive English self-concept alongside CLIL. The role of CLIL was nevertheless emphasized:

(4) It [= strong English skills] is probably not only due to CLIL.. but I'm sure it has had a great impact on it. (Arttu)

In general, the participants saw CLIL as a stepping stone to further learning of English and having created the foundation for their high English self-concept. Three participants even stated how their positive English self-concept had affected their general self-esteem. This is in line with Hardy and Moriarty (2006) who have proposed that the domains of self-concept, which are of high importance to an individual, have an influence on one's global self-esteem. For instance, this seemed to be the case for Kimmo:

(5) Finnish was always quite a hard subject for me.. I never got really good grades from essays.. but then in English I got often ninety nine points [= the maximum] from all those little essays that we had to write.. it was a very important thing to me.. and it probably relates to the fact that I had a better vocabulary or something.. but it's like this that.. that was like.. for my self-esteem it was a very big thing. (Kimmo)

All in all, the findings support the view that CLIL can be a potential setting for developing a positive target language self-concept (e.g. Pihko 2007). However, despite the fact that most participants' English self-concept had remained relatively stable throughout the years, some variation occurred. This issue will be discussed in more detail in the following subsection.

\subsubsection{Dynamic and multidimensional self-concept}


Self-concept is regarded as a dynamic and situational construct that can oscillate throughout the years (e.g. Mercer 2011a, 2011b). The data of the present study further elucidate this. For instance, despite the lack of language anxiety as a general trend, four participants nevertheless reported having experienced some when using English. Their language anxiety seemed to be very context-specific and often occurred when the interlocutor was a native English speaker. It has been found that, in general, Finns tend to feel more comfortable using English with nonnative than native speakers (Leppänen et al. 2011). However, based on the data, it seemed that the participants' language anxiety had not considerably hindered their willingness to interact with others, which may often be the case (e.g. MacIntyre and Gardner 1991). Pihko's (2007) study also revealed that CLIL pupils experience some language anxiety, although to a much lesser extent than their non-CLIL peers. On the other hand, anxiety in language using situations may not always be caused by the foreign language, but may rather reflect general public speaking anxiety as the following extract illustrates:

(6) I wasn't nervous about speaking English.. I have always had this that I am very nervous about speaking in front of people in general.. I do not remember that I would have been more anxious because the language was English.. it didn't matter whether it was in Finnish or English, those have always been a bit sweaty situations. (Kaapo)

In general, the participants seemed to have a strong but realistic self-concept. They were able to identify the language skill domains within a language that they occasionally struggled with, which is a further testimony of the dynamic and multidimensional nature of self-concept (e.g. Mercer 2011b). Three participants associated a momentary decline in their English selfconcept, particularly regarding speaking, with the lack of English use. For two, in turn, university was a period when they had experienced some challenges in written English:

(7) If at some point I have felt that my English language skills haven't been sufficient enough it has been exactly with these scientific publications.. they were hard to understand.. also in English that you sort of.. in theory you understand the text and what is written but then you have to think about it for a long time that what is actually said in it. (Juho)

Even though Juho presents his difficulties with academic texts as a language issue, the problems in his comprehension may partly be due to the scientific language in general, which is often complex with a lot of subject-specific terminology. However, it is plausible that the foreign language element posed an additional challenge. All in all, even though the 
participants' English language self-concept seemed to somewhat vary according to the different skill domains within the language, this did not seem to have a major negative effect on their more global English self-concept.

In contrast to the positive English language self-concept, an issue that was relatively recurrent in the data was a clearly more negative self-concept in other foreign languages, mostly in German and Swedish. These were respectively the two other foreign languages studied in school for most participants. For instance, Tuukka commented on the issue as follows:

(8) For instance German.. I don't know how to speak it at all.. neither do I understand it.. if someone starts to speak German.. I don't understand almost anything.. almost the same with Swedish.. listening comprehension is very bad. (Tuukka)

10 participants explicitly associated their difficulties in other languages with CLIL (see also Roiha and Sommier 2018). That is, they felt that learning English implicitly through content had been counterproductive to their learning of other foreign languages which had been taught more explicitly. They considered that due to CLIL, they did not have the skills to study a language in a more traditional way and described other languages (mostly German and Swedish) as 'difficult', 'arduous' or 'useless'. Their negative attitude towards and struggles with other foreign languages can be interpreted to have had a direct bearing on their selfconcept in those languages, and contrarily further reinforced their already positive English selfconcept. In addition to those 10 participants, 6 other participants also portrayed a rather negative self-concept in other languages. There was one exception in the data, Hanna, who depicted a more positive Swedish self-concept than that of English. She nevertheless considered English her strongest foreign language which, in her view, was a reflection of CLIL.

In conclusion, the fact that many participants seemed to clearly differentiate between their language-specific self-concepts supports the views brought up by Mercer (2011b) that, as opposed to approaching the foreign language self-concept holistically, it may be more reasonable to consider specific self-concepts for different foreign languages. Furthermore, the variations in the participants' different English skills raises the need to distinguish even more domain-specific self-concepts within a language, such as EFL writing, speaking or reading selfconcept (cf. Lau et al. 1999).

\subsection{Factors influencing English language self-concept}


Even though a salient theme in the data was that the majority of the participants considered CLIL having a pervasive influence on them as language users, the participants articulated more precisely certain factors which enhanced their English self-concept. The most recurrent themes in that regard were the emphasis on early language learning, comparison to others and external feedback.

\subsubsection{Early language learning}

Studies on early language learning have shown that pupils with an early start in language learning possess a more positive attitude towards a foreign language and are more willing to use it than their later starting peers (e.g. De Bot 2014; Muñoz and Singleton 2011). The present data are in accordance with this as the early start seemed to have positively affected the participants' English self-concept. This issue was brought up by 18 of the participants. The target CLIL program started in the $1^{\text {st }}$ grade and some had already received minor CLIL in preschool (pupils' age 6-7). For instance, the following quote from Anna illustrates hew view of valuing the early start of CLIL:

(9) I think everyone should have an early start [with CLIL] because I feel that if you look at our class compared to others, our English skills were much better and it was like a lot easier because we had got the small basis for it through songs and play, so kind of in a very simple way. (Anna)

The significance of the early start of CLIL was emphasized especially by the participants whose academic performance was below average. For instance, Kaapo, whose studies were limited to upper secondary school as he went on to have a career as a professional athlete, highlighted the early start of CLIL in forming his positive outlook towards English. As opposed to other school subjects, English had always been easy and pleasant for him:

(10) I just knew that I was good at it [= English] and the things were easy for me.. I liked being there [= English lessons] but I have never liked school.. you were at school from eight till four and after that I didn't do anything for school.. I played hockey and did other stuff. (Kaapo)

When analyzing Kaapo's quote in relation to Marsh's (1986) I/E model, it seems that his negative attitude towards other school subjects had a counter effect on his attitude towards 
English. That is, the internal comparisons he made between different subject-specific selfconcepts had further enhanced his English self-concept.

Additionally, seven of the participants for whom English had been an integral part throughout their life courses, also referred to the early start of CLIL as a factor influencing their English self-concept. For instance, Niko, who had lived and worked abroad for a long time, still found the early start of CLIL significant for his English skills:

(11) The basic level that we got from school so early helped in that we kind of got a couple of years of immersion for free.. and of course it has been a great advantage that you have been able to start it early.. the playing with the language.. after that it has come on a silver platter the whole language. (Niko)

A theme that was fairly recurrent in the data, was the reciprocal relation between the participants' self-concept and their language use situations. Early CLIL had helped form a high English self-concept which encouraged the participants to communicate in English at a young age. The successful outcomes of these situations had in turn reinforced their positive English self-concept (see also Pihko 2007). For instance, Kimmo brought forth how early English skills had given him access to international forums on the internet which was quite exceptional for a young pupil at that time:

(12) I have these memories that I have been in some chat rooms and I have written in English and then when I have told them that I come from Finland and.. that I am like quite young.. then I have gotten praises that wow you are.. you are totally fluent in this. (Kimmo)

In conclusion, the participants seemed to value the early start of CLIL in forming their English self-concept. Furthermore, none of the participants commented on any negative aspects on the early start with CLIL. This finding encourages the implementation of CLIL already at (pre-) primary level. Naturally, one can argue whether the strong English self-concept is the result of early start, CLIL methods, combination of the above or additional factors, but the participants seemed to give credit to the early start regardless of their later life paths. In general, it is acknowledged that the factors influencing one's self-concept are interrelated (e.g. Mercer 2011b). Also in the present study, the early start of CLIL partly intersected with other influencing factors such as social comparisons and external feedback which are further discussed as follows. 


\subsubsection{Comparison to others and feedback}

The data illustrate how the participants' English self-concept was also influenced by social comparisons and feedback from significant others. For instance, family members were a frame of reference for six participants. The comparisons to their siblings or parents and the feedback they received arguably increased the participants' English self-concept:

(13) It was probably nice that.. that even though you were just a kid you knew something.. and maybe.. knew better than mum or dad. (Hanna)

A more recurrent frame of reference was the participants non-CLIL peers. Nine mentioned having realized their advantage compared to their peers already in primary school. 11 participants, in turn, became conscious of it only in upper secondary school when they merged with their non-CLIL peers in formal English lessons. It can be deduced that these external comparisons have further boosted the participants' English self-concept (see e.g. Marsh 1986).

Overall, the influence of the environment noticing the participants' English skills is quite prominent in the data. After getting a lot of positive feedback, the participants' selfconcept arguably adjusted towards more positive direction. This is in accordance with the conceptualization of self-concept being shaped by our experiences and contexts (e.g. Mercer 2011b). For instance, the environment noticing Anna's language skills, especially spoken English, had clearly boosted her self-concept even though she considered herself not being very motivated or good student in general:

(14) I felt that this has partly led to a kind of complex of being better than others that I never thought that but when everyone kept wondering that ooh, you really are good [at English] then you kind of start thinking that maybe I am. (Anna)

In the target CLIL context, the feedback from the environment was perhaps more meaningful than nowadays, as in the early 1990s, when CLIL was something new and language contacts were more infrequent, early start with English was generally perceived as something special. For instance, Roni's quote encapsulates this view:

(15) Perhaps it was more emphasized then that we are somehow a special class. (Roni) 
Stressing the special nature of the class had arguably affected and reinforced the participants' self-concept. If the environment has underlined the speciality of the class, it has inevitably had an effect on the participants' perceptions of themselves as language learners. For instance, Pesu (2017) has found that the feedback from both parents and teachers is important in forming one's self-concept.

In addition to feedback from other people, school grades appeared to be one type of external frame of reference that boosted the participants' English self-concept. For instance, more than half of the ones who completed upper secondary school obtained the highest grade in the English language matriculation examination which, at the national level, only 5 percent of the cohort receive. This seemed to be of high importance to the participants and five of them even explicitly emphasized how they took the examination unprepared, which reflects their strong self-concept and even their sense of superiority in English.

All in all, the findings demonstrate how self-concept is not formed in a vacuum but rather in relation to internal and external factors (e.g. Marsh 1986; Mercer 2011b). However, it is important to bear in mind that the extent to which the early CLIL, social comparisons, external feedback or other factors have affected the participants' English self-concept cannot be distinguished from one another. Nevertheless, the results of this study provide important implications to language teaching which are discussed next.

\section{Implications and conclusion}

This study focused on former pupils' perceptions of the influence of English-medium CLIL on their target language self-concept. The majority of the participants underlined the importance of CLIL in forming their positive English language self-concept. CLIL was perceived as a stepping stone to using English later in life. Despite sporadic downturns as English users and slight variations in their skill-specific self-concepts, their global English self-concept seemed to have remained relatively stable and strong. Additionally, this study scrutinized the factors potentially influencing the participants' English self-concept. The study elucidates the importance of social comparisons and external feedback in forming one's self-concept. Particular emphasis was given to the early start of CLIL which had made it possible for the participants to operate in communicative situations in English at a young age. The successful outcomes of those interactions had reciprocally reinforced their positive English self-concept.

Overall, the findings reveal that CLIL education can be an effective teaching approach regarding the target language self-concept, thus coinciding with the results obtained by Pihko 
(2007) and Rumlich (2016). The opposite results by Seikkula-Leino (2007) about CLIL pupils' low self-concept seem to remain as an exception. However, comparing the present study to the previous studies is somewhat arbitrary due to the slightly different definitions of self-concept as well as the different methodological approaches (i.e. quantitative or qualitative).

The results of this study have both theoretical and practical implications. However, it is important to bear in mind that the participants received their CLIL education in the 1990s, and the conceptualization of CLIL as well as CLIL practices have since evolved. Regardless, the results encourage schools to provide CLIL education. More specifically, even though most CLIL programs focus on secondary education (e.g. Dalton-Puffer 2011), the present study implies the significance of an early CLIL in creating a positive target language self-concept (in the present context CLIL started at the age of 7). Furthermore, the study suggests that it may be worthwhile to adopt CLIL methodology also to mainstream language education as already fairly moderate CLIL seems to be beneficial to the target language self-concept (in the present context the amount of CLIL was approx. $25 \%$ of the overall teaching). Finally, a pivotal result which should not be overlooked is the participants' rather negative self-concept regarding other foreign languages. This result is contradictory to studies on non-CLIL early language teaching that have found an early start resulting in a positive attitude towards languages in general (Muñoz and Singleton 2011). This suggests that in CLIL context, multilingualism should be explicitly acknowledged so that the CLIL language would not cast aside other foreign languages (see also Roiha and Sommier 2018). One solution is to offer a multitude of languages already at primary level. For instance, Finnish immersion education, where the pupils have been exposed to four languages before the age of 12, has led to more positive attitude towards the different languages (Björklund and Mård-Miettinen 2011). As this is a qualitative case study, further studies are needed to see if similar CLIL education in other countries and settings provides comparable observations, or whether the results of the present study are specific only to this particular Finnish CLIL context and cohort.

On a theoretical level, the data support the current view that self-concept should not be regarded as a static and fixed but rather as a dynamic and fluid construct which may vary in time and place (e.g. Mercer 2011b). Second, the findings propose that in contrast to approaching the foreign language self-concept as a generic construct it may be more feasible to break it down into smaller components such as English language self-concept or German language self-concept. Moreover, the participants' narrations encourage to scrutinize the language-specific self-concepts even in more nuanced ways. (see also Mercer 2011b.) However, the data only touched upon this issue and are therefore fairly limited in that regard. 
Thus, CLIL pupils' self-concept in more specific skills within a language as well as in other foreign languages could be further studied. For instance, it would be interesting to investigate the types of CLIL practices and learning environments that best support pupils' various skillspecific self-concepts such as speaking, reading, writing and listening self-concept.

This study has some limitations which are worth mentioning. First, the participants received 2 hours of formal English teaching alongside CLIL per week from 3rd grade onwards which has plausibly had its effect on their English self-concept. Particularly, in lower and upper secondary schools, the formal English lessons, and the social comparisons the participants made to their non-CLIL peers, appeared to reinforce their strong self-concept. Thus, it can be interpreted that the formal English lessons played a somewhat central role in contributing to the participants' self-concept. All in all, the participants' English self-concept seemed to have been formed in an interplay between several factors, such as CLIL, formal English lessons and English using situations outside school. However, the participants seemed to interpret CLIL as the most central and identifiable element in this nexus of factors. Finally, it is worth noting that even though retrospective reflections have their benefits, they also have their limitations. As McAdams (2008) has pointed out, people's later life trajectories and events may impact the way they remember prior experiences or the meanings they attach to them. Therefore, the participants of the present study may also have perceived their CLIL time as more meaningful to their self-concept than in reality. Regardless of these limitations, the study contributes to the current work on self-concept, particularly in relation to CLIL.

\section{Acknowledgements}

This work was partly supported by the Finnish Cultural Foundation's Central Finland Regional Fund.

The data that support the findings of this study can be requested from the corresponding author (Roiha). The data are not publicly available as the transcripts of the interviews contain information that could compromise the privacy of research participants.

\section{Disclosure statement}

No potential conflict of interest was reported by the authors.

\section{References}


Bandura, A. 1986. Social foundations of thought and action: A social cognitive theory. Englewood Cliffs, NJ: Prentice-Hall.

Björklund, S., and K. Mård-Miettinen. 2011. "Integrating multiple languages in immersion: Swedish immersion in Finland." In Immersion education: practices, policies, possibilities, edited by D. J. Tedick, D. Christian, and T. W. Fortune, 13-35. Bristol: Multilingual Matters.

Bong, M., and E. M. Skaalvik. 2003. "Academic Self-Concept and Self-Efficacy: How Different Are They Really?” Educational Psychology Review 15 (1): 1-40.

Braun, V., and V. Clarke. 2006. "Using thematic analysis in psychology." Qualitative Research in Psychology 3 (2): 77-101.

Breen, M. 2001. "Over participation and covert acquisition in the language classroom." In Learner contributions to language learning: new directions in research, edited by $\mathrm{M}$. Breen, 112-143. New York: Longman.

Burns, R. 1982. Self-concept development and education. London: Holt, Rinehart and Winston.

Coyle, D., P. Hood, and D. Marsh. 2010. CLIL: Content and language integrated learning. Cambridge University Press.

Csizér, K., and M. Magid. 2014. "The Self-Concept and Language Learning: An Introduction.” In The Impact of Self-Concept on Language Learning, edited by K. Csizér, and M. Magid, 1-6. Bristol: Multilingual Matters.

Dalton-Puffer, C. 2011. "Content-and-language integrated learning: from practice to principles?" Annual Review of Applied Linguistics 31: 182-204.

De Bot, K. 2014. "The effectiveness of early foreign language learning in the Netherlands." Studies in second language learning and teaching 4 (3): 409-418.

Doiz, A., and D. Lasagabaster. 2018. “Teachers' and Students' Second Language Motivational Self System in English-Medium Instruction: A Qualitative Approach.” TESOL Quarterly 52 (3): 657-679.

Dörnyei, Z. 2005. The Psychology of the Language Learner: Individual Differences in Second Language Acquisition. Mahwah, New Jersey: L. Erlbaum.

Dörnyei, Z. 2009. “The L2 Motivational Self System.” In Motivation, language identity and the L2 self, edited by Z. Dörnyei, and E. Ushioda, 9-42. Bristol: Multilingual Matters.

Dörnyei, Z. and A. Al-Hoorie. 2017. "The motivational foundation of learning languages other than Global English: Theoretical issues and research directions." Modern Language Journal 101 (3): 455-468. 
Dörnyei, Z., and E. Ushioda. 2009. "Motivation, language identities and the L2 self: Future research directions." In Motivation, language identity and the L2 self, edited by Z. Dörnyei, and E. Ushioda, 350-356. Bristol: Multilingual Matters.

Garton, S., and F. Copland. 2010. “'I like this interview; I get cakes and cats!': the effect of prior relationships on interview talk." Qualitative Research 10 (5): 533-551.

Graham, K. M., Y. Choi, A. Davoodi, S. Razmeh, and L. Q. Dixon. 2018. "Language and Content Outcomes of CLIL and EMI: A systematic review." Latin American Journal of Content and Language Integrated Learning 11 (1): 19-37.

Hardy, L., and T. Moriarty. 2006. "Shaping Self-Concept: The Elusive Importance Effect." Journal of Personality 74 (2): 77-402.

Harter, S. 2006. “The self." In Handbook of Child Psychology: Social, Emotional, and Personality Development, edited by N. Eisenberg, W. Damon, and R. M. Lerner, 505570. Hoboken: John Wiley \& Sons Inc.

Konttinen, M. 2018. "Students at the Core of English-Medium Instruction: Research on the Study Paths of International Master's Degree Students and the Role of Academic English and Literacies." PhD diss., University of Jyväskylä.

Laine, E., and M.-K. Pihko. 1991. Kieliminä ja sen mittaaminen: the foreign language selfconcept and how to measure it. University of Jyväskylä.

Lau, I. C., A. S. Yeung, P. Jin, and R. Low. 1999. "Toward a Hierarchical, Multidimensional English Self-Concept.” Journal of Educational Psychology 91 (4): 747-755.

Lehti, L., H.-M. Järvinen, and E. Suomela-Salmi. 2006. "Kartoitus vieraskielisen opetuksen tarjonnasta peruskouluissa ja lukioissa [An inquiry about the status of CLIL education in comprehensive schools and high schools].” In Kielenoppija tänään - Language learners of today, edited by P. Pietilä, P. Lintunen, and H.-M. Järvinen, 293-313. Jyväskylä: AFinLA yearbook.

Leppänen, S., A. Pitkänen-Huhta, T. Nikula, S. Kytölä, T. Törmäkangas, K. Nissinen, L. Kääntä et al. 2011. National survey on the English language in Finland: Uses, meanings and attitudes. Helsinki: Studies in Variation, Contacts and Change in English. http://www.helsinki.fi/varieng/series/volumes/05/

MacIntyre, P. D., and R. C. Gardner. 1991. "Methods and results in the study of anxiety in language learning: A review of the literature." Language Learning 41 (1): 85-117.

Markus, H., and P. Nurius. 1986. "Possible selves.” American Psychologist 41 (9): 954-969.

Marsh, H. W. 1986. "Verbal and Math Self-Concepts: An Internal/External Frame of Reference Model." American Educational Research Journal 23 (1): 129-149. 
Marsh, H. W. 1990. “A Multidimensional, Hierarchical Model of Self-Concept: Theoretical and Empirical Justification.” Educational Psychology Review 2 (2): 77-172.

Marsh, H. W., B. M. Byrne, and R. J. Shavelson. 1988. “A Multifaceted Academic SelfConcept: Its Hierarchical Structure and Its Relation to Academic Achievement.” Journal of Educational Psychology 80 (3): 366-380.

Marsh, H. W., and R. G. Craven. 2006. "Reciprocal Effects of Self-Concept and Performance From a Multidimensional Perspective." Perspectives on Psychological Science 1 (2): $133-163$.

Marsh, H. W., and O. Köller. 2003. "Bringing together two theoretical models of relations between academic self-concept and achievement." In International advances in self research, edited by H. W. Marsh, R. G. Craven, and D. M. McInerney, 17-47. Greenwich, CT: Information Age Publishing.

Marsh, H. W., and R. J. Shavelson. 1985. "Self-Concept: Its Multifaceted, Hierarchical Structure." Educational Psychologists 20 (3): 107-123.

Marsh, H. W., U. Trautwein, O. Lüdke, O. Köller, and J. Baumert. 2005. “Academic SelfConcept, Interest, Grades, and Standardized Test Scores: Reciprocal Effects Models of Causal Ordering." Child Development 76 (2): 397-416.

Marsh, H. W., U. Trautwein, O. Lüdke, O. Köller, and J. Baumert. 2006. "Integration of Multidimensional Self-Concept and Core Personality Constructs: Construct Validation and Relations to Well-Being and Achievement." Journal of Personality 74 (2): 403-456.

McAdams, D. P. 2008. "Personal narratives and the life story." In Handbook of personality: Theory and research, edited by O. P. John, R. W. Robins, and L. A. Pervin, 241-261. New York: Guilford Press.

Mercer, S. 2011a. "Language learner self-concept: Complexity, continuity and change." System 39 (3): 335-346.

Mercer, S. 2011b. Towards an understanding of language learner self-concept. Dordrecht: Springer.

Mercer, S. 2014. "Re-imagining the Self as a Network of Relationships." In The Impact of SelfConcept on Language Learning, edited by K. Csizér, and M. Magid, 51-72. Bristol: Multilingual Matters.

Muñoz, C., and D. Singleton. 2011. "A critical review of age-related research on L2 ultimate attainment." Language Teaching 44 (1): 1-35. 
Nikula, T., and D. Marsh. 1996. Kartoitus vieraskielisen opetuksen tarjonnasta peruskouluissa ja lukioissa [An inquiry about the status of CLIL education in comprehensive and high schools]. Helsinki: The Finnish National Board of Education.

Norton, B. 2013. Identity and Language Learning: Extending the Conversation. 2nd ed. Bristol: Multilingual Matters.

Pavlenko, A., and B. Norton. 2007. "Imagined communities, identity, and English language learning." In International Handbook of English Language Teaching, edited by J. Cummins, and C. Davison, 669-680. Boston: Springer.

Peltoniemi, A., K. Skinnari, K. Mård-Miettinen, and S. Sjöberg. 2018. Monella kielellä Suomen kunnissa 2017. Selvitys muun laajamittaisen ja suppeamman kaksikielisen varhaiskasvatuksen, esiopetuksen ja perusopetuksen tilanteesta [In many languages in Finnish municipalities 2017. A report on the state of other extensive and small-scale bilingual early childhood education, pre-primary education and basic education]. University of Jyväskylä.

Pérez-Cañado, M. L. 2012. "CLIL research in Europe: past, present, and future.” International Journal of Bilingual Education and Bilingualism 15 (3): 315-341.

Pesu, L. 2017. "The role of parents' and teachers' child-related competence beliefs in the development of students' self-concept of ability.” PhD diss., University of Jyväskylä.

Pihko, M.-K. 2007. Minä, koulu ja englanti. Vertaileva tutkimus englanninkielisen sisällönopetuksen ja perinteisen englannin opetuksen affektiivisista tuloksista [Me, school and English. A comparative study of the affective outcomes of English teaching in content and language integrated (CLIL) classes and in traditional foreign language classes]. University of Jyväskylä: Department of teacher education, Research report 85.

Pižorn, K. 2017. "Content and language integrated learning (CLIL): A panacea for young language learners?" In Early language learning. Complexity and mixed methods, edited by J. Enever, and E. Lindgren, 201-221. Bristol: Multilingual Matters.

Roiha, A. 2017. "CLIL-opetuksen merkitys elämänkulkujen rakentajana: Kahden entisen oppilaan pohdintoja [The significance of CLIL as a constructor of life courses: Two former pupils' reflections]." In Kielitietoisuus eriarvoistuvassa yhteiskunnassa language awareness in an increasingly unequal society, edited by S. Latomaa, E. Luukka, and N. Lilja, 257-277. Jyväskylä: AFinLA yearbook.

Roiha, A. 2019. “Investigating former pupils' experiences and perceptions of CLIL in Finland: a retrospective analysis." Nordic Journal of Studies in Educational Policy. Advance online publication. DOI: 10.1080/20020317.2019.1586514 
Roiha, A. and M. Sommier. 2018. "Viewing CLIL through the eyes of former pupils: insights into foreign language and intercultural attitudes." Language and Intercultural Communication 18 (6): 631-647.

Rubio, F. 2014. "Self-Esteem and Self-Concept in Foreign Language Learning." In Multiple Perspectives on the Self in SLA, edited by S. Mercer, and M. Williams, 41-58. Bristol: Multilingual Matters.

Rumlich, D. 2016. Evaluating bilingual education in Germany: CLIL students' general English proficiency, EFL self-concept and interest. Frankfurt am Main: Peter Lang.

Seikkula-Leino, J. 2007. "CLIL Learning: Achievement Levels and Affective Factors." Language and Education 21 (4): 328-341.

Shavelson, R. J., J. J. Hubner, and G. C. Stanton. 1976. "Validation of construct interpretations." Review of Educational Research 46 (3): 407-441.

Tracey, D., A. S. Yeung, A. K. Arens, and C. Ng. 2014. "Young Second Language Learners' Competence and Affective Self-concept." Asian EFL Journal 16 (4): 76-95.

Tuomi, J., and A. Sarajärvi. 2009. Laadullinen tutkimus ja sisällönanalyysi [Qualitative research and content analysis]. Helsinki: Tammi. 


\section{Appendix 1: Two participant's coding sheets as an example}

\begin{tabular}{|c|c|c|}
\hline no language anxiety in English & \multirow{4}{*}{ Robust English SC } & \multirow{8}{*}{ Manifestation of English SC } \\
\hline sense of superiority & & \\
\hline self-confidence to use English language at work -> privileged position & & \\
\hline English as a language of thought & & \\
\hline downturn in SC $->$ university studies & Dynamic SC & \\
\hline specific language skills: language use, communication & \multirow{3}{*}{ Multidimensional SC } & \\
\hline limitation in English skills -> lack of vocabulary & & \\
\hline perceived himself as bad at other languages -> partly due to CLIL & & \\
\hline the naturalness of English early on & \multirow{4}{*}{ The significance of early CLIL } & \multirow{7}{*}{ Factors influencing English SC } \\
\hline the easiness of English early on & & \\
\hline implicit learning of English & & \\
\hline influence of CLIL on communication at a young age & & \\
\hline comparing to others, (lower and upper secondary, university of applied sciences) & \multirow{3}{*}{$\begin{array}{c}\text { Social comparisons \& external } \\
\text { feedback }\end{array}$} & \\
\hline language use at work $->$ feedback from others, comparing to others & & \\
\hline the significance of school grades (upper secondary school) & & \\
\hline
\end{tabular}

\begin{tabular}{|c|c|c|}
\hline CLIL created self-confidence to use English & \multirow{5}{*}{ Robust English SC } & \multirow{10}{*}{ Manifestation of English SC } \\
\hline worked abroad using English -> self-confidence & & \\
\hline considers having more courage to use English than other Finns & & \\
\hline considered himself as better at English than others in general & & \\
\hline sees the confidence in English as partly guiding his career choices & & \\
\hline minor language anxiety when speaking with English native speakers & Dynamic SC & \\
\hline considered speaking as his weakest area & \multirow{4}{*}{ Multidimensional SC } & \\
\hline CLIL increased vocabulary and speaking in particular & & \\
\hline views writing as his strongest skill in English & & \\
\hline $\begin{array}{l}\text { compares his English to Swedish -> lacks the courage to use Swedish }->\text { lack of } \\
\text { self-confidence }\end{array}$ & & \\
\hline did not perceive CLIL as anything special as it started in the $1^{\text {st }}$ grade & \multirow{4}{*}{ The significance of early CLIL } & \multirow{8}{*}{ Factors influencing English SC } \\
\hline positive memories of CLIL $->$ could not come up with anything negative about it & & \\
\hline motivation to study English early on & & \\
\hline English-medium lessons mixed in the head with Finnish-medium lessons & & \\
\hline in upper secondary noticed being better than average $->$ obtained good grades & \multirow{4}{*}{$\begin{array}{l}\text { Social comparisons \& external } \\
\text { feedback }\end{array}$} & \\
\hline particularly noticed the difference at university in oral skills & & \\
\hline ahead of peers also in vocabulary and speaking & & \\
\hline received the highest grade in the matriculation examinations & & \\
\hline
\end{tabular}




\section{Appendix 2: The participants' study history and English use after CLIL (Adapted from Roiha 2019)}

\begin{tabular}{|c|c|}
\hline Anna (F) & $\begin{array}{l}\text { - English-medium master's degree abroad } \\
\text { - had lived and studied in an English-speaking country for several years }\end{array}$ \\
\hline Annika (F) & $\begin{array}{l}\text { - a degree from a university of applied sciences (only a few English courses) } \\
\text { - occasional use of English at work and in free time }\end{array}$ \\
\hline Arttu (M) & $\begin{array}{l}\text { - in the midst of completing his master's degree (English-medium courses) } \\
\text { - frequent use of English at work }\end{array}$ \\
\hline Eemeli (M) & $\begin{array}{l}\text { - master's degree (English-medium courses) } \\
\text { - frequent use of English at work }\end{array}$ \\
\hline Emmi (F) & $\begin{array}{l}\text { - master's degree (English-medium courses) } \\
\text { - frequent use of English at work }\end{array}$ \\
\hline Hanna (F) & $\begin{array}{l}\text { - dual degree from upper secondary and vocational school (only a few English courses) } \\
\text { - occasional use of English at work }\end{array}$ \\
\hline Jere (M) & $\begin{array}{l}\text { - degree from a university of applied sciences (only a few English courses) } \\
\text { - had been on a work placement abroad for } 6 \text { months using English } \\
\text { - occasional use of English at work and in free time }\end{array}$ \\
\hline Jonne (M) & $\begin{array}{l}\text { - vocational degree (only a few English courses) } \\
\text { - occasional use of English at work and in free time }\end{array}$ \\
\hline Juho (M) & $\begin{array}{l}\text { - English-medium master's degree } \\
\text { - frequent use of English at work }\end{array}$ \\
\hline Jukka (M) & $\begin{array}{l}\text { - vocational degree (only a few English courses) } \\
\text { - frequent use of English at work and in free time }\end{array}$ \\
\hline Kaapo (M) & $\begin{array}{l}\text { - matriculation examination certificate } \\
\text { - had lived and worked abroad for several years } \\
\text { - English partly as a working language }\end{array}$ \\
\hline Kalle (M) & $\begin{array}{l}\text { - master's degree (English-medium courses) } \\
\text { - frequent use of English at work }\end{array}$ \\
\hline Kimmo (M) & $\begin{array}{l}\text { - master's degree abroad (first two years English-medium) } \\
\text { - occasional use of English at work }\end{array}$ \\
\hline Lotta $(\mathrm{F})$ & $\begin{array}{l}\text { - degree from a university of applied sciences (only a few English courses) } \\
\text { - occasional use of English in free time }\end{array}$ \\
\hline Maria $(F)$ & $\begin{array}{l}\text { - in the midst of completing her master's degree (English-medium courses) } \\
\text { - occasional use of English at work and in free time }\end{array}$ \\
\hline Marko (M) & $\begin{array}{l}\text { - master's degree (English-medium courses) } \\
\text { - frequent use of English at work }\end{array}$ \\
\hline Niko (M) & $\begin{array}{l}\text { - master's degree (English-medium courses) } \\
\text { - lived and worked abroad } \\
\text { - English as working language; main language also in free time }\end{array}$ \\
\hline Olli (M) & $\begin{array}{l}\text { - bachelor's degree (only a few English courses) } \\
\text { - occasional use of English at work and in free time }\end{array}$ \\
\hline Pasi (M) & $\begin{array}{l}\text { - master's degree (English-medium courses and exchange year abroad) } \\
\text { - had lived and worked abroad for four years } \\
\text { - English as working language; main language also in free time }\end{array}$ \\
\hline Riikka (F) & $\begin{array}{l}\text { - English-medium master's degree } \\
\text { - occasional use of English at work }\end{array}$ \\
\hline Roni (M) & $\begin{array}{l}\text { - in the midst of completing his master's degree (English-medium courses) } \\
\text { - frequent use of English at work, occasional use in free time }\end{array}$ \\
\hline Samu (M) & $\begin{array}{l}\text { - studied in university of applied sciences (only a few English courses) } \\
\text { - frequent use of English at work, occasional use in free time }\end{array}$ \\
\hline Sanna (F) & $\begin{array}{l}\text { - English-medium master's degree } \\
\text { - had studied and lived abroad several years } \\
\text { - English as working language; main language also in free time }\end{array}$ \\
\hline Tuukka (M) & $\begin{array}{l}\text { - master's degree (English-medium courses) } \\
\text { - occasional use of English at work and in free time }\end{array}$ \\
\hline
\end{tabular}




\section{Appendix 3: The quotes in the original language}

(1) Suomalaiset sitten puhuu [englantia] silleen aika hyvin ja sill.. mut se on kuitenkin silleen välillä vähän sinne päin että.. tulee semmosia joitain virheitä jotka ei ehkä itellä sitten. (Eemeli)

(2) Kyl se [= CLIL] niinkun roh.. sellasta rohkeutta on antanut silleen.. itseluottamusta käyttää englantia. (Pasi)

(3) Mä niinkun luotan siihen kielitaitoon että.. kyllä mä niinkun että tavallaan uskaltaa just lähtee puhumaan ja on sitä.. niinkun sitä var.. sanavarastoo tuolla ja semmosta niin.. kyllä mä niinkun tosi paljon niinkun laitan sen [= CLIL-opetuksen] piikkiin että. (Annika)

(4) Ei se [= vahva englannin taito] pelkästään tän enkkupainotteisuuden ansiota varmastikaan oo.. oo mutta.. kyllä sillä varmasti iso vaikutus siihen on ollu. (Arttu)

(5) Mulla oli niinkun äidinkieli aika vaikea aine et mä en saanu koskaan kirjotuksista mitään kauheen hyviä numeroita.. mut sit taas enkussa niinkun kaikista niistä pikkuesseistä mitä piti kirjottaa niin mä sain tosi usein ysiysi pistettä [= maksimi].. se oli mulle tosi tärkee juttu että.. ja se varmaan liitty siihen et mulla oli parempi sanavarasto tai jotain.. mut että se on niinkun sellanen että.. joka niinkun oli.. oli mun itsetunnolle tosi iso juttu. (Kimmo)

(6) En mä niinkun englannin puhumista jännittänyt.. mulla on aina ollu sellanen että mä oon jännittäny puhumista yleisesti niinkun muiden edessä.. en mä ainakaan muista että mä oisin siitä niinkun englannin kielellä esiintymisestä mitenkään sen kummemmin ottanu stressiä et se on ollu ihan.. ihan sama onko se ollu suomen kielellä tai englannin kielellä se puhuminen niin se on ottanu aina vähän hikeä pintaan. (Kaapo)

(7) Jos jossakin vaiheessa on niinkun kokenu että englannin kielen taito ei ole riittävä niin ne on nää niinkun.. nimenomaan tieteellisissä julkasuissa olevat tieteelliset.. tai niinkun tieteelliset artikkelit joita lukee.. ne oli kyllä vaikeita ymmärtää.. englannikskin et sä niinkun.. periaatteessa ymmärrät sen tekstin mitä siinä sanotaan mut että.. sit sä jouut tosi pitkään miettimään että.. et mitä sillä tarkotetaan tai niinkun. (Juho)

(8) Esim saksa niin ei osaa niinkun yhtään puhua.. ja enkä ymmärräkkään.. jos joku lähtee puhuun saksaa niin en.. en mä niinkun ymmärrä sitä niinkun juuri ollenkaan.. sama on melkein ruotsi.. kuullun ymmärtäminen todella huono. (Tuukka)

(9) Mun mielestä kaikilla pitäis alkaa se [= CLIL-opetus] niinkun niin aikasin koska musta tuntuu että.. että jos niinkun katotaan meijän luokkaa verrattuna muihin.. niin meijän englanninkieli oli paljon parempi ja niinkun et se.. se oli niin paljon helpompaa sen takia et me oltiin saatu se semmonen pieni pohja siihen mikä oli just sitte semmosta laulua ja leikkiä että tosi niinkun tavallaan.. yksinkertasella tavalla. (Anna)

(10) Mä vaan tiesin et mä oon niinkun hyvä [englannissa] ja ne asiat on mulle silleen helppoja että.. siellä [= englannin tunneilla] oli mukava olla mutta mä en oo ikinä niinkun tykänny koulunkäynnistä.. koulussa oltiin kaheksasta neljään ja sit sen jälkeen mä en tehny mitään koulun eteen.. pelattiin lätkää ja muita juttuja. (Kaapo)

(11) Se pohjataso mikä tuli sieltä koulusta niin aikasin niin se autto sit taas siihen et on niinkun ilmaset muutama vuos sitä immersiota.. ja siis toki ollu tosi paljon etuu siitä et siinä on niinkun päässy niin varhain alottaan ton kielen kans pelaamisen et se on niinkun tullu sen jälkeen ihan niinkun hopeelautasella koko kieli. (Niko)

(12) Semmosii muistoja on ku on just ollu jossain chattihuoneessa ja sitten kirjottanu englantii niin sitten kun on sanonu et on Suomesta niin sitten.. ja et on niinkun aika nuori.. niin sit on saanu kehuja et vau kylläpä sä.. sähän oot ihan fluent tässä. (Kimmo)

(13) Olihan se varmasti mukavaa että.. että kuitenkin ku ite oli ihan lapsi niin jotain osas.. ehkä.. osas enemmän ku äiti tai isä. (Hanna)

(14) Musta tuntu että osaks siitä on myös sen takia tullu semmonen joku paremmuuskompleksi että ei sitä ennen ollu ite niin ajatellukkaan mutta sit ku kaikki ihmiset päivittelee aina sitä että no ootpas sä kyllä hyvä [englannissa] niin sit sitä on silleen no kyllä mä varmaan sit oon niinkun että. (Anna)

(15) Ehkä sillon enemmän korostettiin sitä että ollaan jotenkin erikoinen luokka. (Roni) 